\title{
Lean Startup as a Learning Methodology for Developing Digital and Research Competencies
}

\author{
Carolina Ávalos ${ }^{1} \odot$, Ana Pérez-Escoda ${ }^{2} \odot$ and Luis Monge ${ }^{3} \odot$ \\ ${ }^{1}$ Department of Curriculum and Didactics, Universidad Estatal a Distancia, Costa Rica \\ ${ }^{2}$ Department of Communication, Nebrija University, Spain \\ ${ }^{3}$ Department of Information Technologies, Universidad Estatal a Distancia, Costa Rica
}

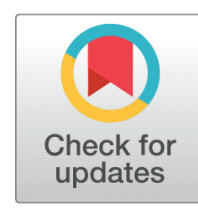

Received 14-05-2019
Revised 17-05-2019
Accepted 13-06-2019
Published 15-07-2019

Corresponding Author

Carolina Ávalos,

cavalos@uned.ac.cr

10304, Desamparados, San

Rafael Arriba. San José, Costa

Rica.

DOI https://doi.org/10.7821/

naer.2019.7.438

Pages: 227-242

Distributed under

Creative Commons CC BY 4.0

Copyright: (C) NAER Journal of New Approaches in Educational Research 2019

\section{OPEN ACCESS}

\section{ABSTRACT}

The acquisition of digital and research competencies for educating university students is a requirement that is becoming more relevant given the demands of today's society. However, learning methodologies used by professors seem to be detached from reality, preventing the development of applicable learning, as well as the acquisition of those skills necessary in the twenty-first century. The main objective of the research is to analyze the Lean Startup method as a learning methodology in the creation of digital and research competencies in students from the UNED Costa Rica during the development of the course: Mixed Methods Research (MMR). The sample consisted of 531 individuals, teachers and students from different degrees of the School of Education from the UNED who took the course during the years 2015 to 2017. A mixed explanatory sequential design was used, with a theoretical part of an exploration of the method, a quantitative part (descriptive analysis and contrast of means) and another qualitative part by means of content analysis. The results showed the effectiveness of an innovative methodology such as Lean Startup in the development of digital and research skills, and the change of the teacher's role in the teaching process.

\section{INTRODUCTION}

In terms of development and social responsibility, the universities of this century are called upon to permanently strive to educate individuals and to contribute to the improvement of regions and countries (Hernández, Mora, \& Luna, 2017). However, certain authors in their research, such as Cajide et al. (2002), Voogt and Roblin (2012), Clemente and Escribá (2013) have pointed out the need for universities to be more linked to the requirements of companies as well as to the needs and demands of society, taking into account the daily reality which is where the different skills and abilities acquired during the years of study 
are put to test. In this way, the other conglomerate of capacities, abilities and skills for the integral development of the professional can start to be considered in the processes of professional training.

From research carried out on the subject ever since the beginning of the 21st century (OCDE, 2005; OECD, 2018; Rychen \& Salganik, 2000) we can find an international concern towards the appropriate skills that the education system must provide for citizens to face the challenges of the new century. Skills such as learning to innovate, digital and office literacy, improving people's personal and professional life, as well as axiological and ethical training, are some of those that stand out in the current century. Authors such as Luna (2015) and Figueroa (2017) coincide in the need to acquire skills such as those indicated which prepare citizens for current challenges and demands, thus highlighting the need to rethink the learning methodology towards roles and training spaces that are more participatory and applied to experiential contexts.

In this sense, from different international contexts the appropriate skills for this century have been defined, from diverse models of development arising from the association of universities such as Partnership for 21st Century (2009); from international organisms such as UNESCO (2008 2016) and OECD (2018), from the European Union (Vuorikari, Punie, Carretero, \& Brande, 2016) or from the national scope, in this case Costa Rica (Zúñiga, Núñez, Brenes, \& Chacón, 2013).

However, from the responsibility that universities must assume in providing solutions to the demands of society, Shank (2011) criticizes that, from the reality of the system, there is a decontextualized training of the needs of each population. That is to say a learning system which lacks meaning and in its absence, reproduces contents that are not significant for the students in their training, and develops tough competition, instrumental abilities and skills without the necessary understanding to be adapted to real scenarios. As stated by Alabart (sf) (quoted in Borafull 2014), "the current educational system forces everyone to go through the tube of homogenization, not considering individual talents and instilling knowledge of a generic and non-significant character" (p. 156).

According to the scenario presented and focusing on digital and research competencies, it can be assured that the student body in its training process receives instruction about the use of technological resources and knowledge mainly of bibliographic research processes (Campos \& Chinchilla, 2009; Jou \& Wang, 2013; López, 2013; Rectores, 2017), However, none of these inputs refer to the acquisition of digital and research competencies from an innate understanding, nor, to how the development of such skills allows students to transfer the knowledge acquired to other scenarios from intrinsic processes.

\subsection{Digital competencies}

Digital competency, as such, appears in the European Reference Framework in 2006 in recognition of the European Union of basic skills that every citizen of the 21st century should develop in order to be competent: Recommendation of the European Parliament and of the Council of December 18, 2006 on key competencies for lifelong learning. Although digital competency was recognized and defined as one of the 8 basic competen- 
cies, it was not until 2013 (Ferrari, 2013) that a well-founded definition was established:

Digital competency is a set of knowledge, skills, attitudes, strategies, values and awareness required when using ICT and digital media to perform tasks, solve problems, communicate, manage information, collaborate, create and share content and build knowledge in an effective, efficient, appropriate, critical, creative, autonomous, flexible, ethical and reflective way for work, leisure, participation, learning, socialization, consumption and empowerment (Ferrari, 2013, p. 4)

This study takes the European Reference Framework as a theoretical base, in which the reference framework and understanding of digital competency is developed in 2013 (Ferrari, 2013) and revised in 2016 (Vuorikari et al., 2016). Following this, the following digital competencies have been identified for our study (Vuorikari et al., 2016)

- Information management: related to effective searches, evaluation, storage and retrieval of information.

- Communication: including all communicative actions carried out through ICT tools (social networks, blogs, chats, etc.).

- Content creation: such as the ability to create all kinds of content (blogs, websites, wikis, presentations, infographics, etc.).

- Problem solving: with a specific focus on critical thinking and problem solving centered on technology and with the effective ability to find answers to questions posed.

- Security: related to digital identity management, privacy, configuration of tools and profiles, etc.

\subsection{Research competencies}

In 2010, the Organization for Economic Cooperation and Development established a series of research competencies to be developed in the twenty-first century, those that would promote problem solving actions to solve problems for reflective thinking, ethical and social impact, communication, adaptability and organization; such competencies will be considered in the analysis of this research, since they have been reinforced thanks to studies conducted by Jou and Wang (2013), Davison and Palermo (2015), Luna (2015) and Anderson (2016), which have coincided with the approaches of the OECD.

Currently one of the main concerns of the education system is the lack of research skills in the training of its professionals, as has been demonstrated in recent years, from statistical reports such as the State of Education and studies developed in Costa Rican territory, highlighting the lack of research productions from this sector (Ávalos, 2018).

Taking into account the competency needs of the 21 st century and considering the contributions of Riyanti, Sandroto, and DW (2017), Borafull (2014), Luna (2015), and Gisbert and Lázaro (2015), on the skills that every professional must develop in this century, the search for emerging methods was carried out. This took place in those disciplines where successful results had been identified allowing for the development of metacognition spaces, which were missing in the teacher training of UNED students. In this way, the Lean Startup Method became relevant to be applied as a learning methodology. 


\subsection{Lean Startup as a learning methodology}

The Lean Startup method was created by Erick Ries in 2011. According to Ries, the method enhances those "practices that favor the creation of Startups successfully and with little likelihood of experiencing losses" (Ries, 2011, p. 39). It is based on the scientific method for its execution and considers a series of steps that are fundamental in its development: creating, measuring and learning.

Authors such as Fishbein (2014), Gutiérrez and Apaolaza (2014), Ritika (2015) and Peñalver (2017) perceive a diversified implementation of the method from areas other than Business Administration, thereby promoting the development of a new learning methodology that favors processes such as:

- The contextualization of knowledge: working with learning experiences with a realistic approach, promoting an improvement of mindset and problem solving.

- The development of entrepreneurial attitudes: by enhancing collaborative work, creative mentality, effective communication, permanent observation, experimentation, analysis of situations, development of innovative proposals. All of which, together with technological resources can appropriate the student body with digital competency and from design processes, with the measurement of proposals, the verification and socialization of results and the research competency.

- The development of soft skills is encouraged: those that predispose students to adopt changes and adjust to them in a proactive way, to be empathetic, to know how to look for solutions to different situations, to develop divergent thinking, processes of self-motivation and thus flexible and innovative thinking.

\section{METHOD}

The study took place in three stages during the years 2015-2017, and included as a study population the student body of the School of Educational Sciences, who were taking the course Mixed Methods Research (MMR).

During the assessment stage, a documentary review was developed, as well as the implementation of instruments to students and teachers, together with processes to improve the learning methodology. In the processual stage and final stage of research, the course was developed with the incorporation of the Lean Startup method as a learning methodology. This implied making use of techniques and strategies such as Project Based Learning (PBL), research seedbeds, collaborative work and mediating the development of conceptual and procedural knowledge of the subject through the use of tools such as: wiki, reflective journals, academic forums, chat, Skype, WhatsApp and Google drive, all conducive to effective communication, self-regulation of learning, teamwork, divergent thinking and solving situations, conducive to learning for life (Riyanti et al., 2017). These modifications were generated in 2016 and implemented in 2017, with the objective of testing the effectiveness of the Lean Startup method as a learning methodology to guarantee building digital and research competencies in the student body of the subject Mixed Methods Research. 
The study is framed within a descriptive, explanatory and applied research which has been developed in three stages: diagnostic, processual and final (Pérez, 2006). It is an explanatory sequential mixed type (Creswell, 2015), which seeks to respond to the phenomenon studied by contrasting qualitative and quantitative data (Pérez, Galán, \& Quintanal, 2012).

\subsection{Sample}

The study was carried out with students from different degrees of the Faculty of Educational Sciences who were studying the course Mixed Methods Research during the years 2015 to 2017 and professors who offered the subject during those years. In practice, there was a total sample of 531 subjects of which 319 were women and 212 were men; the average age of the participants was between 30 to 50 years old. Sampling was carried out for the diagnostic and processual stage in a simple random probability with $95 \%$ reliability and a $5 \%$ margin of error, considering 116 students and 3 teachers in the diagnostic stage, 201 students in the processual stage who participated in the survey and a review of performance reports of 173 other students in the subject. The final stage was done in a non-probabilistic way for convenience, working with a group of 33 students and 5 teachers from the course (Sáez, 2017).

\subsection{Creation of the survey}

In the diagnostic and processual stage, two surveys were designed as data collection instruments with the intention of knowing the achievement of digital and research competencies reached by the students in the course. Each survey consisted of 5 parts: sociodemographic information, methodology used, methodological strategies, ICT resources used, research skills and abilities achieved at the end of the course; Likert scales were used in its deployment. Also, interviews were conducted with teachers in the diagnostic stage. In the final stage, interviews were conducted with students and teachers, as well as observation processes using checklists. The validation of the surveys and interviews was carried out by experts in the areas of Technology, Pedagogy and Research prior to deploying them to the participating sample (McMillan \& Schumacher, 2005). The variables to be analyzed were: the acquisition of digital and research competencies as dependent variables and as independent variables: learning methodology, ICT resources and learning experiences.

\subsection{Reliability of the survey}

For the quantitative part of the survey, the statistical package SPSS was used, highlighting a normal distribution in the behavior of the variables, the factorial analysis technique was used to determine the correlation of the variables; from the results of KMO and Bartlett tests, a high level of correlation between the factors 0.903 was shown, with a high significance. Justifying the results obtained by the Cronbach's Alpha test, which determined a high reliability in the instruments 0.91 for the survey used in the diagnostic stage with 76 elements and 0.94 for the survey applied in the processual stage, which consisted in 92 ele- 
ments; In the qualitative part, the content analysis technique was used with the tool Atlas Ti (Bisquerra, 2014).

\section{ANALYSIS AND RESULTS}

\subsection{Initial and processual stage}

With a percentage of less than $50 \%$ of the sample surveyed, the student body determined, in the diagnostic study, that the methodology developed by teachers in the course MMR was from Good to Very Good, highlighting aspects such as counseling (32.8\%) and followup meetings (42\%). ICT resources most used in the mediation of the subject were: the notification board (37.1\%), the academic forum (32.8\%), platform mail (32.8\%) and from learning experiences, the technique of Project-Based Learning (PBL), through the development of research projects, as the technique most used in the development of the subject (see Figure 1).

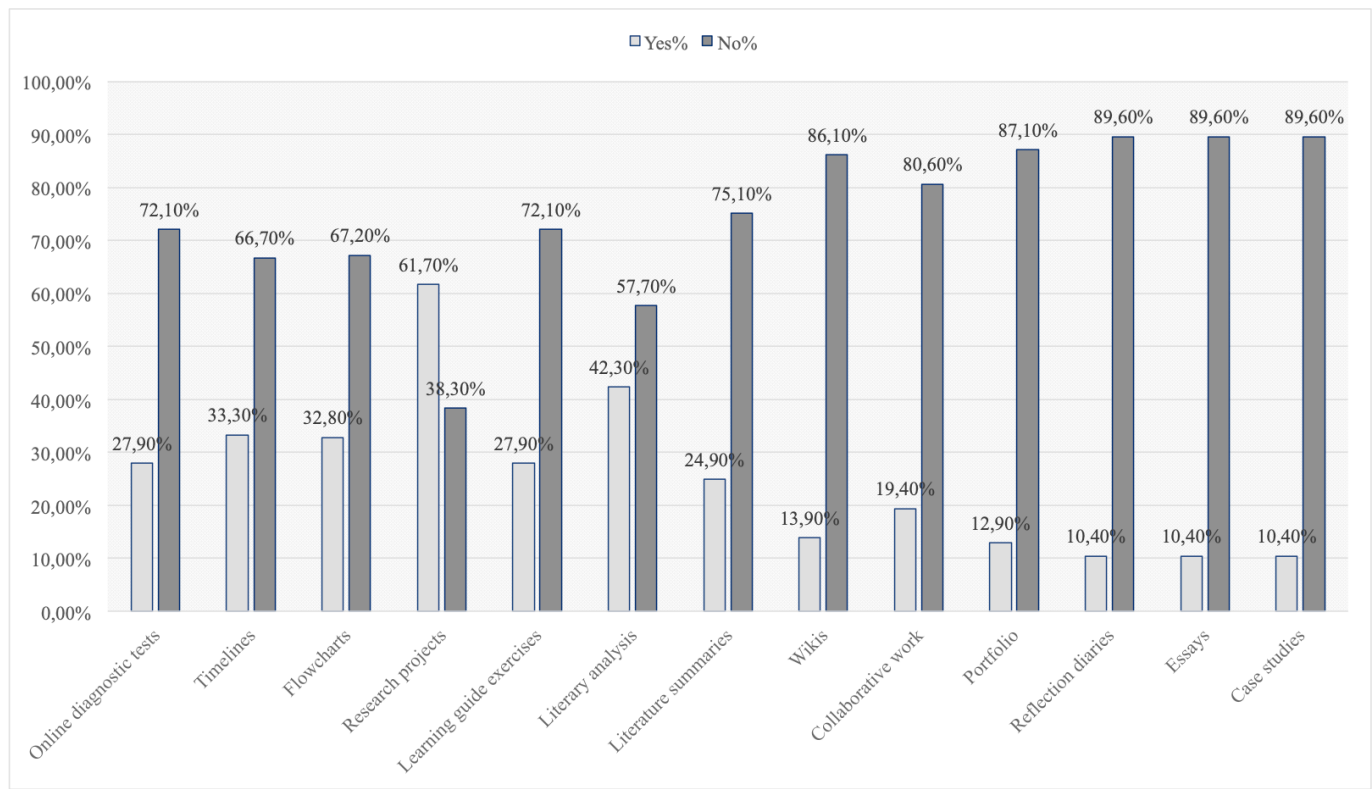

Figure 1 Ávalos (2018) . Learning experiences through the use of ICT resources 2015-2016.

In the processual stage, a review of the methodology used by teachers in 2015-2016 was carried out, based on the ANOVA test. Generally speaking it was evident that the methodology did not vary from one year to another in spite of the changes in the learning experiences, aspects such as: follow-up (M1) p=.078/ $3131 \mathrm{~F}$, motivation in the course of activities (M 4) $p=.076 / 3167 \mathrm{~F}$ and fulfillment of learning objectives (M 5) $p=.476 / .509 \mathrm{~F}$, did not show differences in the items analyzed from one year to another. Out of the twelve methodology variables reviewed, the only one that showed any variation was (M 6), in environments of respect and collaboration, $\mathrm{p}=.018 / 5645 \mathrm{~F}$; the data is detailed inTable 1 . 


\begin{tabular}{|c|c|c|c|c|c|c|c|}
\hline Method & $\mathbf{M}$ & SD & $\mathbf{F}$ & gl & $p$ & Eta2 & Dir. \\
\hline M1 & 3.51 & 1.33 & 3131.0 & 1 & .078 & .0098 & $\mathrm{M} 3>\mathrm{M} 1$ \\
\hline M2 & 3.51 & 1.21 & .757 & 1 & .385 & .0024 & $\mathrm{M} 3>\mathrm{M} 2$ \\
\hline M3 & 3.53 & 1.17 & .013 & 1 & .908 & .0000 & $M 6>M 3$ \\
\hline M4 & 3.48 & 1.18 & 3167.0 & 1 & .076 & .0100 & $\mathrm{M} 1>\mathrm{M} 4$ \\
\hline M5 & 3.49 & 1.25 & .509 & 1 & .476 & .0000 & M3 $>$ M5 \\
\hline M6 & 3.57 & 1.24 & 5645.0 & 1 & $.018^{\star}$ & .0176 & $\neq>\mathrm{M} 6$ \\
\hline M7 & 3.55 & 1.22 & 2043.0 & 1 & .154 & .0064 & M6>M7 \\
\hline M8 & 3.46 & 1.24 & 2039.0 & 1 & .154 & .0064 & $\mathrm{M} 4>\mathrm{M} 8$ \\
\hline M9 & 3.43 & 1.20 & 3156.0 & 1 & .077 & .0000 & M11>M9 \\
\hline M10 & 3.54 & 1.19 & .679 & 1 & .411 & .0000 & $\mathrm{M} 7>\mathrm{M} 10$ \\
\hline M11 & 3.49 & 1.27 & 1630.0 & 1 & .203 & .0000 & $\mathrm{M} 3>\mathrm{M} 11$ \\
\hline M12 & 3.42 & 1.24 & 1424.0 & 1 & .234 & .0045 & M5>M12 \\
\hline
\end{tabular}

Note $\mathrm{N}=317 ; \mathrm{M} 1=$ The tutor accompanied and followed the learning processes of the students; M2 = The tutor was a facilitator and counsellor; M3 = The tutor stated that he was available to the student body; M4 = The tutor constantly invited the student body to carry out the activities; M5 = The tutor was attentive to the development and fulfilment of the learning objectives; M6 = The tutor promoted respectful learning environments and collaborators; M7 $=$ The tutor demonstrated a broad mastery of the contents; M8 = The tutor accompanied the student, assessed and feedback on the quality of thinking strategies; M9 = Previous knowledge acquired in previous courses was taken into account; M10 = From the type of assessment made by his tutor, active participation was promoted throughout the course. M11 = The feedback received contributed to improving, broadening or reinforcing the learning process; M12 = Self-evaluation, co-evaluation and hetereoevaluation were promoted throughout the different activities. ${ }^{*} \mathrm{p}<0.05$

Subsequently, a correlation was made between the items of the methodology and digital competencies (CD) and research (CI) to determine the behavior of the variables in the acquisition of competencies according to the methodology used. For this purpose, a factorial analysis was first carried out to group the competencies, highlighting from the matrix of components a reduction of factors to two predominant components in the digital competency (CD): information management (.649) and problem solving using critical thinking (-.617). In the case of research competencies (IQ) one component was highlighted: communication (.701). Once the competency factors were identified, the correlation was made with the methodology used by the teaching staff, highlighting a significance in the digital information management competency (CD 2, see Table 2) with regard to the other two competencies.

The results in table 2 demonstrate a high significance that is changing in information management $(\mathrm{CD} 2)$ in contrast with the methodology variables, with $\mathrm{p}<.05$. This means that the (CD2) is going to increase or decrease according to the type of methodology developed by the teaching staff in the subject. Problem solving (CD1) and communication competencies (CI) did not achieve this significance which, according to the data presented, seem to require another type of methodology that favors the development of these competencies in learning processes. 
Table 2 Correlation between methodology and digital (CD) and research (CI) competencies

\begin{tabular}{llll} 
Method & \multicolumn{3}{l}{ Competencies } \\
\hline M1 & CD1 & CD2 & CI \\
M2 & .039 & $-.229^{\star}$ & -.025 \\
M3 & .032 & $-.210^{\star}$ & -.120 \\
M4 & -.026 & $-.264^{\star *}$ & -.113 \\
M5 & -.042 & $-.208^{\star}$ & -.142 \\
M6 & .008 & $-.277^{\star *}$ & -.078 \\
M7 & .086 & -.169 & -.051 \\
M8 & -.016 & -.165 & -.113 \\
M9 & -.041 & $-.209^{\star}$ & -.088 \\
M10 & -.035 & $-.299^{\star *}$ & -.073 \\
M11 & .039 & $-.248^{\star *}$ & -.080 \\
M12 & .059 & $-.185^{\star}$ & -.055 \\
\hline
\end{tabular}

Note $\mathrm{N}=116 ; \mathrm{CD} 1$ = Problem solving; $\mathrm{CD} 2=$ Information management; $\mathrm{CI}=$ Communication; $\mathrm{M} 1=$ The tutor accompanied and followed up the students' learning processes; M2 = The tutor was a facilitator and counsellor; $\mathrm{M} 3$ = The tutor stated that he was available to the student body; M4 = The tutor constantly invited the students to carry out the activities; M5 = The tutor was attentive to the development and fulfilment of the learning objectives; M6 = The tutor promoted respectful learning environments and collaborators; M7 = The tutor demonstrated a broad mastery of the contents; M8 = The tutor accompanied him, assessed and feedback on the quality of his thinking strategies; M9 = Previous knowledge acquired in previous courses was taken into account; M10 = From the type of assessment carried out by his tutor, active participation was promoted throughout the course. M11 = The feedback received contributed to improving, broadening or reinforcing the learning process; M12 = Self-evaluation, co-evaluation and hetereoevaluation were promoted from the different activities. ${ }^{*} \mathrm{p}<.05 ;{ }^{* *} \mathrm{p}<.01$

\subsection{Final stage: Digital competency and research through emerging learning methodologies}

After considering the results of the methodology used by the teaching staff during the initial and processual stages, it was possible to demonstrate their responsibilities as platform administrators and not as managers of new knowledge construction processes (Ávalos, 2018). As a result, more than $50 \%$ of the research competencies focused on information search and content analysis capacities, and in percentages lower than 50\% other relevant competencies, such as: problem solving, critical and reflective thinking, ethical-social impact and communication, based on studies by Jou and Wang (2013), and OECD (2018). Among the digital competencies achieved according to the student body and in a percentage greater than $50 \%$ were: a positive attitude towards the use of technological resources and the use of certain tools on the platform, leaving other competencies undeveloped with a percentage data below $40 \%$. These included: communication and collaboration, the creation of digital content in problem solving, which have been supported in studies 
by Brynjolfsson and McAfee (2014), Gisbert and Lázaro (2015) y Rangel (2015), as well as in approaches made by UNESCO (2016). This data is expanded in Table 3.

\begin{tabular}{|c|c|c|c|c|c|}
\hline $\begin{array}{l}\text { Digital Competen- } \\
\text { cies }\end{array}$ & Capabilities & f & Yes \% & f & No $\%$ \\
\hline \multirow{3}{*}{$\begin{array}{l}\text { Critical and reflec- } \\
\text { tive thinking }\end{array}$} & AOpen and critical attitude towards the Information Society and ICTs. & 69 & $59,50 \%$ & 47 & $40,50 \%$ \\
\hline & $\begin{array}{l}\text { Development of reflective thinking from the impact of ICT on social life, considering the } \\
\text { social, economic and cultural implications for the individual and society. }\end{array}$ & 55 & $47,40 \%$ & 61 & $52,60 \%$ \\
\hline & $\begin{array}{l}\text { Renewal and permanent updating of knowledge based on the pedagogical and research use } \\
\text { of ICTs. }\end{array}$ & 20 & $17,20 \%$ & 96 & $82,80 \%$ \\
\hline Problem solving & Construction of digital content of benefit for their learning. & 39 & $33,60 \%$ & 77 & $66,40 \%$ \\
\hline $\begin{array}{l}\text { Information man- } \\
\text { agement }\end{array}$ & Effective educational use of Web 2.0 resources. & 25 & $21,60 \%$ & 91 & $78,40 \%$ \\
\hline \multirow{2}{*}{$\begin{array}{l}\text { Communication } \\
\text { and collaboration }\end{array}$} & Teacher-student interaction capacities through telematic media. & 25 & $21,60 \%$ & 91 & $78,40 \%$ \\
\hline & Encourage the development of learning networks. & 20 & $17,20 \%$ & 96 & $82,80 \%$ \\
\hline \multirow{5}{*}{$\begin{array}{l}\text { Safety in the instru- } \\
\text { mental use of tools }\end{array}$} & Office automation: word processor, spreadsheets, databases. & 47 & $40,50 \%$ & 69 & $59,50 \%$ \\
\hline & Digital images: scanner, camera, digital video, screen captures. & 63 & $54,30 \%$ & 53 & $45,70 \%$ \\
\hline & Hypertext handling capabilities, such as writing and writing in the digital environment. & 29 & $25,00 \%$ & 87 & $75,00 \%$ \\
\hline & Basic knowledge of computer systems and networks. & 23 & $19,80 \%$ & 93 & $80,20 \%$ \\
\hline & Ability to use e-mail. & 40 & $34,50 \%$ & 76 & $65,50 \%$ \\
\hline $\begin{array}{l}\text { Research compe- } \\
\text { tencies }\end{array}$ & Capabilities & $\mathrm{f}$ & Yes $\%$ & $\mathrm{f}$ & No $\%$ \\
\hline $\begin{array}{l}\text { Organization of } \\
\text { information }\end{array}$ & Search, evaluation, selection, organization, analysis and interpretation of information. & 76 & $65,50 \%$ & 40 & $34,50 \%$ \\
\hline $\begin{array}{l}\text { Adaptation to } \\
\text { changes }\end{array}$ & Adaptability to new research and learning formats, methods and methodologies. & 51 & $44,00 \%$ & 65 & $56,00 \%$ \\
\hline $\begin{array}{l}\text { Ethic and social } \\
\text { impact }\end{array}$ & Application of ethical criteria in the responsible use of information. & 52 & $44,80 \%$ & 64 & $55,20 \%$ \\
\hline \multirow[t]{2}{*}{ Problem solving } & Predisposition towards continuous learning and permanent knowledge updating. & 42 & $36,20 \%$ & 74 & $63,80 \%$ \\
\hline & $\begin{array}{l}\text { Development of research work based on the formation of networks with other centers and } \\
\text { peers. }\end{array}$ & 43 & $37,10 \%$ & 73 & $62,90 \%$ \\
\hline \multirow[t]{2}{*}{$\begin{array}{l}\text { Communication } \\
\text { and collaboration }\end{array}$} & $\begin{array}{l}\text { Development of participatory interaction skills facilitating constructive feedback by creating } \\
\text { learning communities. }\end{array}$ & 41 & $35,30 \%$ & 75 & $64,70 \%$ \\
\hline & Development remote collaborative projects between students. & 25 & $21,60 \%$ & 91 & $78,40 \%$ \\
\hline
\end{tabular}

As a product of the previous panorama, the Lean Startup methodology was implemented in the first four-month period of 2017, after the final stage of the study, testing the experience with a group of 33 students from the course Mixed Methods Research. This methodology was based on the redesigning of learning methodology and didactic strategies focused on learning by doing, challenge-based learning, design thinking and mobile learning, which according to Peñalver (2017), are activities that enable the development of skills such as creativity, effective communication, critical thinking, collaborative work and a change of mentality towards innovations. Such changes can be seen in Figure 2 .

In order to develop techniques and strategies linked to collaborative work and (PBL), with the Lean Startup methodology, it was necessary to review the existing tools in Moodle's 
LMS platform, identifying those that would be of greater benefit in the student's analysis and reflection processes for the subject's learning experiences and those which, in addition, would promote collaborative work. Therefore, the use of reflective journals and wiki were some of the tools incorporated into the learning experience, as well as others detailed in the previous table.

The aim was to level the workload on the platform based on the observations made in previous periods (2016-1 and 2016-2), ensuring that the activities were interrelated, so that the group's efforts to generate an electronic dictionary on research topics using the Wiki and individual reflections developed in reflective journals were contributions that assigned more weight to the knowledge of each student in the subject (MMR). This was done in order to generate their own research project approach and make an effective pedagogical use of technological tools that they had not used before, which allowed them to increase their knowledge and practice in the use of technology while developing research knowledge, encouraging also the use of other tools such as Skype, WhatsApp and Chat, and more accompaniment and motivation that was highlighted by the students in the SWOT's (Ávalos, 2018).

As for the development of the subject improvements (MMR), prior to the changes it was necessary to develop a learning methodology, which is presented inFigure 3 with the

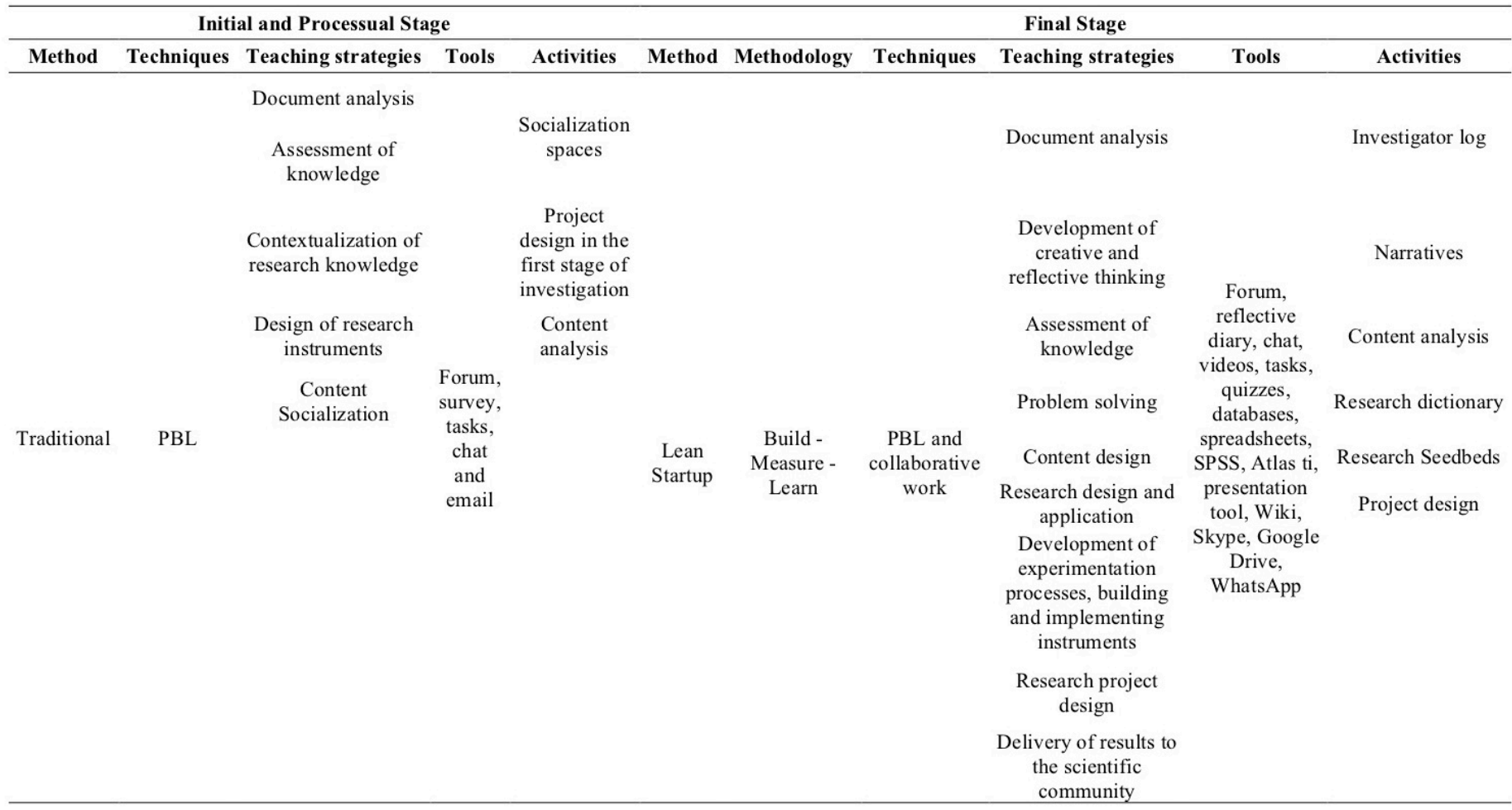

Figure 2 Redesign of teaching strategies 
implementation of the Lean Startup method as a learning methodology.

By materializing the system that underpins the Lean Startup build-measure-learn methodology, it was possible for students to move from a methodology focused on instructional learning to one by doing. In this way, in the building stage the student body developed activities that allowed them to reinforce observation, inquiry, analysis and reflection. They interacted constantly with different tools such as Wiki in collaborative learning spaces for the development of a digital dictionary on research topics, with the reflective diary in the development of weekly annotations, sensitizing their observations on the object of study to be researched. With videos to reinforce thematic contents of the subject, they developed processes of synthesis, verification and application of the theory in identifying their object of study for the development of their research project through the technique (PBL) and collaborative work actions. The teacher was a facilitating agent and mentor who promoted the development of attitudes such as critical thinking, collaborative work, originality, leadership, creativity and transversal values in the education of the student body such as respect, tolerance, empathy and ethics.

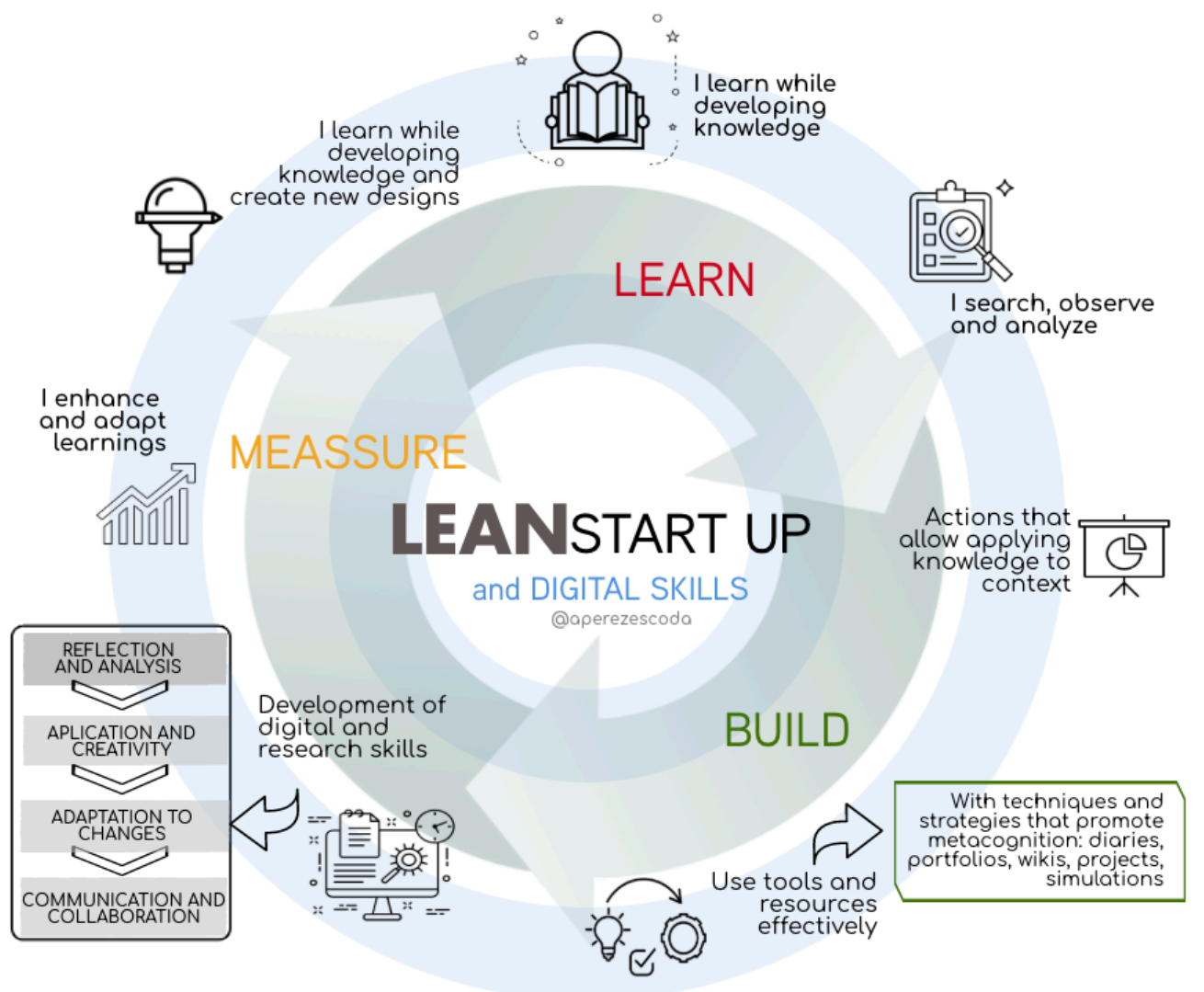

Figure 3 Lean Startup como metodología de aprendizaje

In the measuring stage, in the performance of activities and follow-up of the learning achieved, both the student body and the teacher identified weaknesses and strengths in the 
training processes from actions such as self-evaluation, co-evaluation and one-way evaluation. This was carried out through progress reviews, delivery of reports, participant observation processes, SWOT's delivered by the students themselves on the improvements to be developed in the subject and the work done using wiki, chats, forums and networked media such as Skype. All of this was developed from a philosophy of evaluating to learn. Finally, in the learning process the student body evidenced a change on the importance of research for the improvement of its own didactic model from their work with "Semilleros de investigación" (Seas, 2016), recognizing the importance of collaborative work in the development of research processes and from the use of a methodology oriented towards doing, supported by technological tools of greater interaction. This led to the development of digital and research competencies, which had not been attended, although they had been identified, in the stages of diagnostic and processual research.

As for the interviews with teachers and students in order to validate the effectiveness of a new learning methodology, an electronic interview was conducted ${ }^{1}$; in which both actors agreed that in order to establish improvements in the learning methodology it was necessary to consider aspects such as follow-up, continuous evaluation, development of clear instructions, collaborative work and permanent feedback (interview with teachers, December 22, 2017) and that in order to achieve such improvements it was advisable to first train the teaching team in the Lean Startup methodology and in the tools to be used in virtual environments before implementing a new methodology. They highlighted the importance of entering into new learning practices for achieving contextualized and significant learning, and on the other hand, the need to bear in mind the interests of the university, the increase in the working hours of the team of trainers, since with the current dedication $\left(\frac{1}{4} \mathrm{~T}\right)$ little can be done to generate innovation processes. It also highlights some of the teachers' own impressions of the proposed methodology: P4. "Yes, I agree, being an entrepreneur is an excellent option for the development of competent professionals who are open to the challenges of today's market and labor context". (Professor 4, personal communication, December 22, 2017) (Ávalos, 2018, p. 291), other teacher contributions are also highlighted:

P1. Yes, I agree, from my point of view it is necessary to do different things to obtain different results, it seems to me a viable proposal from the resources required for its implementation and to test different methodologies. (Professor 4, personal communication, December 22, 2017).

P3. Nowadays an entrepreneurial attitude is necessary in any area of life, therefore, in education, considering that it is a field that is continually being renewed, being innovative is a necessity. (Professor 3, personal communication, December 22, 2017).

\footnotetext{
${ }^{1}$ https://youtu.be/TJ6RL0gRBOA
} 


\section{DISCUSSION AND CONCLUSIONS}

The changes evidenced in the role of the teacher, the methodology used, the techniques and didactic strategies used with technological support from an effective and didactic mediation, favored in the final stage of the research, the achievement of the learning experience and the development of research and digital competencies such as collaborative work, problem solving, critical and reflective thinking, communication and ethical attitude. These results reinforce the conclusions of other similar studies by Gupte (2015), Link (2016), Siddiq, Scherer, and Tondeur (2016), and Patiño, Cruz, and Gómez (2016), in which it was demonstrated that the inclusion of innovative methodological practices fostered the transversal competency development of students.

Furthermore, from the acquisition of digital competencies, the results of the research made it clear that in the initial and processual stages, only the competence of an open attitude towards the knowledge society and the use of digital resources had been evidenced in a percentage greater than 50\%, prevailing among learners a lack of knowledge of office automation skills and a complete lack of ubiquitous understanding of technological tools to transform the learning achieved in real-world solutions. This complemented the contributions of López (2013), Sevillano and Vázquez (2015) and Sepúlveda et al. (2017).

Therefore, with the implementation of the Lean Startup methodology, it was possible to show that digital competencies based on the approaches of Rangel (2015), Fernández and Fernández (2016), -referring to the effective use of information, communication from network spaces, information management, use of ethics, creation of educational content, responsible use of technologies, improvement proposals from concrete and realistic applicable actions- could be developed during the different learning experiences and work methodology implementing the phases of the Lean Startup method: building, measuring and learning.

Bearing this in mind the acquisition of soft skills such as self-regulation, self-motivation, a mind set for coping with change, communication, leadership and empathy is emphasized (Patiño et al., 2016). Coincidentally, the skills mentioned are compatible with others favored by the Lean Startup Method established by Riyanti et al. (2017) and Peñalver (2017): namely communication, teamwork, creativity and problem solving.

According to Borafull (2014) the contributions on the reality of companies are, as he states: "currently developed within networks of cells with their own knowledge and not in pyramids; they do not compete, they communicate, cooperate and create online", (p. 156). Following this, it would appear necessary to rethink the methodologies used to educate professionals, considering from their educational curriculum, the opportunities offered by the Lean Startup method, it can be concluded from their research, that this method is a driver of soft skills within which entrepreneurial thinking takes strength (Gupte, 2015; Schwarts, 2016).

The work presented here reinforces proactive attitudes such as those proposed by Luna (2015) and Sepúlveda et al. (2017) that visualize the possibilities of entrepreneurial thinking as a competency that can be transversal to several areas; from entrepreneurship (Schwarts, 2016; Sepúlveda et al., 2017) , innovation and research (Anderson, 2016; Davison \& 
Palermo, 2015; Jou \& Wang, 2013; Peñalver, 2017) and digital competencies Gisbert and Lázaro (2015); Pérez-Escoda (2017)

Finally, it can be concluded that it is necessary for universities to strive to rethink the current learning methodology, from the use of emerging methods such as Lean Startup and that this methodology focuses on fostering innovation, contextualization and feasibility of knowledge through attitudes that allow the individual to build transformative ideas, to measure their innovations against the demands of the real world and to learn from their mistakes, and improvement opportunities in their learning. Because only then will the acquisition of research and digital competencies be executed in an innate way in the learning processes thus achieving a profile of a comprehensive professional, that meets "in situ" with the demands of this century.

\section{REFERENCES}

Anderson, J. (2016). Inquiry-based learning. Teaching Secondary Mathematics (pp. 117-145). Cambridge: Cambridge University Press. https://doi.org/10.1017/CBO9781316442814.007

Ávalos, C. (2018). Uso del método Lean Startup en el análisis y rediseño de estrategias didácticas para la formación en investigación. Tesis de Doctorado en Educación. Madrid, España. UNED. Recuperado de. Retrieved from https://bit.ly/2SP3Z1V

Bisquerra, R. (2014). Metodología de la Investigación Educativa. Madrid: La Muralla S.A.

Borafull, I. (2014). El futuro de la educación vinculado a un nuevo modelo productivo en una sociedad de cambios disruptivos. Revista de Humanidades, 2, 150-165. Retrieved from https:// bit.ly/1HiF5Nt

Brynjolfsson, E., \& McAfee, A. (2014). The Second Machine Age: Work, Progress, and Prosperity in a Time of Brilliant Technologies. New York: Norton \& Company. Retrieved from https://bit.ly/ $1 \mathrm{~L} 103 \mathrm{Gk}$

Cajide, J., Porto, A., Abeal, C., Barreiro, F., Zamora, E., Expósito, A., \& Mosteiro, J. (2002). Competencias adquiridas en la universidad y habilidades requeridas por los empresarios. Investigación Educativa, 20(2), 449-467. Retrieved from https://bit.ly/2EJq4JY

Campos, J., \& Chinchilla, A. (2009). Reflexiones acerca de los desafíos en la formación de competencias para la investigación en la educación superior. Actualidades Investigativas en Educación, 2, 1-20. Retrieved from https://bit.ly/2IYs72e

Clemente, R., \& Escribá, C. (2013). Análisis de la percepción de las competencias genéricas adquiridas en la Universidad. Revista de Educación, 362, 535-561. Retrieved from https://bit.ly/ $2 \mathrm{NNpMGj}$

Creswell, J. (2015). A Concise Introduction to Mixed Methods Research. USA, Los Angeles: Sage.

Davison, Z., \& Palermo, C. (2015). Developing Research Competence in Undergraduate Students through Hands on Learning. Journal of Biomedical Education, 1, 1-9. https://doi.org/10.1155/ 2015/306380

Fernández, F. J., \& Fernández, M. J. (2016). Los docentes de la Generación Z y sus competencias digitales. Comunicar, 46, 97-105. https://doi.org/10.3916/C46-2016-10

Ferrari, A. (2013). A framework for developing and understanding digital competence in Europe. Retrieved from http://goo.gl/sbPQB7

Figueroa, M. (2017). Habilidades del Siglo XXI para todos. Compartir palabra maestra. Retrieved from https://bit.ly/2rrs4mB

Fishbein, M. (2014). Lean Education: What College Students Can Learn From Lean Startups. 
Retrieved from https://bit.ly/1wUIyes

Gisbert, M., \& Lázaro, J. L. (2015). Professional development in teacher digital competence and improving school quality from the teachers perspective: a case study. New Approaches. Educational Research, 4(2), 115-122. Retrieved from https://bit.ly/2TpfiD9 https://doi.org/10.7821/ naer.2015.7.123

Gupte, A. (2015). The Very Lean Startup Method. Journal for Contemporary Research in Management, 7, 52-57. Retrieved from https://bit.ly/2SOE8qP

Gutiérrez, A., \& Apaolaza, U. (2014, July). Lean Startup como herramienta para la generación de un modelo de negocio basado en la gestión de medios digitales. Congreso Internacional de Dirección de Proyectos e Ingeniería, July, 16-18, Alcañiz. Retrieved from https://bit.ly/2nOFXWk Recuperado de.

Hernández, A., Mora, J., \& Luna, J. (2017). Universidad y Empresa: Un Binomio de Responsabilidad Social en el Siglo XXI. Tendencias, 18(1), 145-158. https://doi.org/10.22267/rtend.171801.70

Jou, M., \& Wang, J. (2013). Investigation of effects of virtual reality environments on learning performance of technical skills. Computers in Human Behavior, 29(2), 433-438. https://doi .org/10.1016/j.chb.2012.04.020

Link, P. (2016). How to become a lean entrepreneur by applying lean start-up and lean canvas? Advances in Digital Education and Lifelong Learning, 2, 57-71. https://doi.org/10.1108/S2051 $-229520160000002003$

López, M. (2013). Aprendizaje, Competencias y TIC. México: Pearson Education.

Luna, C. (2015). El futuro del aprendizaje 2 ¿Qué tipo de aprendizaje se necesita en el siglo XXI? (and others, Ed.). UNESCO. Retrieved from https://bit.ly/2vVdHIt

McMillan, J., \& Schumacher, S. (2005). Investigación educativa. Madrid: Pearson.

OCDE. (2005). The definition and selection of key competencies. Executive summary. Retrieved from http://www.oecd.org/pisa/35070367.pdf

OECD. (2018). The Future of Education and Skills. Education 2030. Paris: Institute of Educational Technologies. Retrieved from http://bit.ly/2Wnbi7G

Patiño, O., Cruz, E., \& Gómez, M. (2016). Estudio de las competencias de los emprendedores/innovadores sociales. El caso del Premio ELI de la Universidad EAN. Revista Escuela de Administración de Negocios, 81, 75-90. https://doi.org/10.21158/01208160.n81.2016.1557

Peñalver, P. (2017). Lean Startup en Educación. Emprender no es una opción (Vol. no). Retrieved from http://www.pablopenalver.com/

Pérez, R. (2006). Evaluación de Programas Educativos. Madrid: La Muralla.

Pérez, R., Galán, A., \& Quintanal, J. (2012). Métodos y diseños de investigación en educación. Madrid España: UNED.

Pérez-Escoda, A. (2017). Competencias mediáticas, TIC y competencias digitales. Barcelona: Editorial UOC.

Rangel, A. (2015). Competencias docentes digitales: propuesta de un perfil. Píxel-Bit. Revista de Medios y Educación, 46, 235-248. Retrieved from https://bit.ly/2Ubq24n https://doi.org/ 10.12795/pixelbit.2015.i46.15

Rectores, C. N. (2017). Sexto Informe del Estado de la Educación. Retrieved from https://bit.ly/ $2 \mathrm{fe} 6 \mathrm{eL} 0$

Ries, E. (2011). The Lean Startup. How today's entrepreneurs use continuous innovation to create radically successful businesses. New York: Crown Business.

Ritika, P. (2015). Lean Startup story: from volunteer to entreprenuer. Lean Startup Corporation. Retrieved from https://bit.ly/2XI0Qog

Riyanti, B. P. D., Sandroto, C. W., \& DW, M. T. W. (2017). Soft Skill Competencies, Hard Skill Competencies, and Intention to Become Enterpreneur of Vocational Graduates. International 
Research Journal of Business Studies, 9(2), 119-132. https://doi.org/10.21632/irjbs.9.2.119-132 Rychen, D. S., \& Salganik, L. H. (2000). Defining and selecting key competencies. Göttingen: Hogrefe.

Sáez, J. (2017). Investigación Educativa. Fundamentos teóricos, procesos y elementos prácticos. (Enfoque práctico con ejemplos esencial para TFG, TFM y tesis). UNED España, AEBOE.

Schwarts, B. (2016). Efecto dominó [Rippling]. Como los emprendedores sociales propagan la innovación por todo el mundo. Barcelona: Empresa Activa.

Seas, J. (2016). Didáctica General I. San José: EUNED.

Sepúlveda, J., Denegri, M., Orellana, L., Criado, N., Mendoza, J., Salazar, P., \& Yung, G. (2017). Características emprendedoras personales y alfabetización económica: una comparación entre estudiantes universitarios del sur de Chile. Interdisciplinaria, 34(1), 107-124. Retrieved from https://bit.ly/2UoAs0r https://doi.org/10.16888/interd.2017.34.1.7

Sevillano, M., \& Vázquez, E. (2015). Modelos de investigación en contextos móviles y ubicuos en Educación Superior. Madrid: McGraw-Hill.

Shank, R. (2011). Teaching Minds: How Cognitive Science Can Save Our Schools. New York: College Press.

Siddiq, F., Scherer, R., \& Tondeur, J. (2016). Teachers' emphasis on developing students' digital information and communication skills (TEDDICS): A new construct in 21st century education. Computers \& Education, 92, 1-14. https://doi.org/10.1016/j.compedu.2015.10.006

UNESCO. (2008). Estándares de competencia en TIC para docentes. Retrieved from https://bit.ly/ 2Vru4WD

UNESCO. (2016). Competencias y estándares TIC desde la dimensión pedagógica. Retrieved from https://bit.ly/2ulveWd

Voogt, J., \& Roblin, N. P. (2012). A comparative analysis of international frameworks for 21 st century competences: Implications for national curriculum policies. Journal of Curriculum Studies, 44(3), 299-321. https://doi.org/10.1080/00220272.2012.668938

Vuorikari, R., Punie, Y., Carretero, S., \& Brande, L. V. (2016). DigComp 2.0: The digital competence framework for citizens. Update Phase 1: The Conceptual Reference Model. Luxembourg: European Commission.

Zúñiga, M., Núñez, O., Brenes, M., \& Chacón, D. (2013). La ruta hacia la apropiación de las TIC en los educadores costarricenses. En Cuarto Informe Estado de la Educación. San José: Programa Estado de la Nación. 